\title{
Ideological Factors of Islamic Reference Books Published in Indonesia
}

\author{
Siti Maryam \\ Library and Information Science Department, \\ State Islamic University (UIN) of Syarif Hidayatullah \\ Jakarta, Indonesia \\ siti.maryam@uinjkt.ac.id
}

\begin{abstract}
This paper discussed the result of a research about Islamic reference books publishing in Indonesia, conducted in 2014 by employing qualitative approach. This study aimed at explaining a variety of non-business factors that encouraged the publication of Islamic reference books in Indonesia. The research data obtained through in- depth interviews with some informants from four publishers of the Islamic reference books; publishers from the oldest to the youngest were: CV. Ichtiar Baru Van Hoeve, CV. Almahira, PT. Lentera Abadi, and PT. Kamil Pustaka. The results of this study indicated that there were two main factors outside the business factors that affected the publishing of Islamic reference books in Indonesia. The first factor was the religious spirit of the publishers, and the second factor was the ideals that each publisher wished to achieve. Both of these factors were ideological factors that played an important role for the continuation of the publication of Islamic reference books in Indonesia.
\end{abstract}

Keywords-- Islamic reference books; Islamic publishing; nonbusiness factors; ideological factors

\section{INTRODUCTION}

The publication of Islamic books in Indonesia has been started since 1949 marked by the establishment of Al-Ma'arif Publishers by Baharthah, with the Qur'an as its main issue. In 1951 Bulan Bintang Publisher was founded by Abdul Manaf (Amelz) with his first book titled"Islam dan Sosialismee written by HOS Tjokroaminoto. The Bulan Bintang publishes many translation books and the works of national Islamic figures such as Hasbi As-Shiddieqy, A. Hasjmy, Hamka, Syafruddin Prawiranegara, etc. In the 1960 s to 1970 s Bulan Bintang became the most important Islamic publisher in Indonesia, but in the 1980s its reputation began to decline [1].

The publication of the Islamic book began to rise again in the $1980 \mathrm{~s}$, fueled by excitement over the flourishing of Islamic atmosphere in Indonesia at the time. The excitement was clearly marked by the rising activity of the young generation in campus mosques such as the Salman Mosque (ITB), Arief Rahman Hakim (University of Indonesia) Mosque, Al-Ghifari Mosque (IPB) and Jemaah Saladin (IPB). In this period, a number of Islamic book publishers were born in order to meet the needs of reading for the new generation of Islam, among others are Pustaka Salman (1980), Saladin Press (1983), Mizan (1983), and Gema Insani Press (1986) [1].

The presence of Islamic book publishers has produced Islamic books with more varied topics such as books on Islamic thought and politics, Islamic economics, Islamic art and culture, Islamic philosophy, and so on. Mizan is one example of a publisher concentrating on publishing books on Islamic thought. Besides, there is also progress in terms of presentation of information (content) and artistic. Some writers who appeared in these years include M. Amin Rais, Nurcholis Madjid, AM. Saefuddin, Jalaluddin Rahmat, Kuntowijoyo, Harun Nasution, M. Dawam Rahardjo, M. Quraish Shihab, and others. Further, in the 1980s the bookshops such as Gramedia and Gunung Agung provided considerable places for Islamic books.

The two publishers, Mizan and Gema Insani Press, developed into major Islamic book publishers, while Pustaka Salman had translated important works by Fazlur Rahman (Islamic neo-modernist from Pakistan), and Edward Said's "Orientalism". In the 1990s, this condition was declining, even the Saladin Press, initiated by highly active and dynamic University Gajah Mada students, had stopped publishing books in 1988-1989 estimated due to managerial problems [1].

However, the publication of Islamic books continues, even Islamic reference books that have different characteristics from monographs have begun in the 1990s. Some of the characteristics of reference books such as encyclopedias are usually written by a team of many people, thick physical formats, hard cover, lots of illustrations and color, using good quality paper, and often consist of lots of volume. With these characteristics, the publication of reference books requires high costs, so the price becomes expensive, consequently the sales level is not as high as the sales of textbooks or monographs. Therefore, in Indonesia, reference books are often sold in installments. Thus, there seems to be a contradiction between high production costs on the one hand and low sales levels on the other. However, the publication of Islamic reference books continues to run even increase in 
number from time to time. This is interesting to examine, that in addition to business factors there are other factors that encourage the publication of Islamic reference books.

Some authors have conducted research on the publishing of Islamic books in Indonesia. Halid and Zubair [2] have conducted research on the Role of Publishers in Transformation of Islamic Intellectualism: Survey of Some Islamic Book Publishers in Jakarta. This research focused on the role of publishers in the transformation of Islamic intellectuals in Indonesia. Siti Maryam [3] also has been researching about the productivity of Islamic book publishing in Indonesia by looking at the listing of Islamic books in Indonesian National Bibliographic (BNI). Abdul Munip (2010) has published a book which was the result of his research entitled: Transmisi Pengetahuan Timur Tengah ke Indonesia: Studi Tentang Penerjemahan Buku Berbahasa Arab di Indonesia 1950-2004 (Transmission of Middle Eastern Knowledge to Indonesia: Study of Translation of Arabic Books in Indonesia 1950-2004). This study discussed the growth of Islamic sciences in Indonesia heavily influenced by the translation activities of Arabic books into Indonesian, where most of the books contained Islamic themes. The important conclusion of this research is that the Arabic books translated into Indonesian had great influence on the development of Islamic science and even Islam in Indonesia [4, p. 16].

In contrast to the previous research and writings, this paper discussed the internal factors, especially non-business factors that encouraged the publication of Islamic reference books in Indonesia. This research was conducted in 2014 but the findings are still relevant to be discussed at this time because these factors are believed to be still in effect today.

\section{METHOD}

This paper was the result of descriptive qualitative research that aimed at providing a very detailed description of the situation, social environment or a relationship, explaining in detail the various social activities, exploring new issues or explaining why something happened (Neuman, $p$ 2930). This paper also explored the non-business factors of Islamic reference books publishing in Indonesia. The primary data were obtained from in-depth interviews with the leaders of Islamic reference books publishers: Starlita (from Ichtiar Baru van Hoeve), Abdul Ghofar (from Almahira), Budi Sudharmono (from Lentera Abadi), and Muhammad Kosim ( $f$ rom Kamil Pustaka). While the supporting data (secondary data) were obtained from various sources, both printed sources such as books, articles or research reports, and online sources whether from the publisher's web itself or from other related sites.

\section{RESULT AND DISCUSSION}

The non-business factors in publishing the Islamic reference book means discussing all the non-profit-oriented factors, also the ideology that encourages the publication of the Islamic reference book. The definition of ideology here is in accordance with the understanding put forward by $\mathrm{M}$. Sastraprateja, that ideology is a tool of ideas or action-oriented thinking that is organized into a regular system [5]. So in this paper the non-business or ideological aspects are covering ideals, thoughts, and beliefs that affect the Islamic reference book publication in Indonesia. Here are the non- business or ideological aspects drive the successful publication of Islamic references book in Indonesia.

The first factor is the ideals of the publishers themselves. From interviews with informants, it is well known that Islamic book publishers generally have the same ideals, desires, and visions related to the publication of Islamic references books: the desire to contribute something of value and benefit to the progress of civilized society, taking part in the intellectualizing of the people (nation) by providing authoritative and qualified reading materials. Abdul Ghafar, [6] the informant from PT. Almahira explicitly stated that as a publisher, Almahira has a noble aspiration which was to provide the ways or means for Indonesian Muslims to study their religion (such as about prayer, zakat, inheritance, etc.) through authoritative sources. Therefore, Almahira publishes Islamic reference books that can be read by all Indonesian Muslims regardless of their background (mazhab, flow, and understanding).

The reality of Islamic religious diversity in Indonesia (understanding, madhhab, and flow) has inspired and encouraged Almahira to publish Islamic reference book that can meet the information needs of all Muslims. Almahira wants the reference book published can be read by all Muslim groups. Strictly Abdul Ghafar said that the book he published is really not in favor of certain thoughts or schools, so that all Muslims are expected to use the book whether they are from the Muhammadiyah, the Nahdhatul Ulama, Persis, or from other circles. The book he presented really wanted to display information about the teachings of Islam as a whole based on the Qur'an and As-Sunnah and not partial (not in favor of one particular school or stream). Therefore, if there is a book containing discourse or disagreement on a topic, the theme is thoroughly and comprehensively discussed by presenting the views of the opposing parties, then being informed which of these opinions are considered the most valid accompanied by arguments, historical facts and a valid social fact to answer the question. It can be considered as Almahira's efforts to participate in purifying the teachings of Islam through the Islamic references books he published.

In line with Almahira, Kamil Pustaka also aspires to publish books that are impartial to one school, so this publisher seeks to publish a reliable Islamic references book (qualified, authoritative in terms of content and good physical format), which can be read by all Muslims in the Indonesia. According to Muhammad Kosim [7] editor-in-chief of Kamil Pustaka, to realize these ideals PT. Kamil Pustaka was very selective in selecting a team of authors who compiled a book to be published, for example by a policy of choosing author names that were perfectly acceptable to the public at large and did not involve the names of authors who were deemed to be representative or voiced particular group thinking. Kosim 
gave an example if there was a name of the author who was very famous, but the daily life of his family is not in accordance with what he wrote then the author is not accepted, because he considered that the book would not be accepted by all Indonesian Muslims.

The ideal of CV. Ichtiar Baru, van Hoeve, is spreading knowledge extensively. The company wants to disseminate knowledge and, scientific information in all fields of science to the whole society, especially on scholars, scientists, lecturers, faculty and students. Starlita [8] the informant from CV. Ichtiar Baru did not specifically mention her ideals regarding the publication of Islamic reference books, but it can be assumed that knowledge of Islam was part of the knowledge that must be disseminated through the various encyclopedias.

In contrast to the three publishers, Lentera Abadi publishes Islamic reference books because the books are indeed needed by the community. According to Budi Sudharmono (general marketing manager of PT Lentera Abadi) public awareness of Islamic books was increasing even though their reading interest has not increased significantly. Therefore Lentera Abadi seeked to increase the reading interest by publishing books that are good and interesting format (esiklopedia"s design). Through the encyclopaedia, information can be presented along with pictures, illustrations, and other completeness of information with great interest, and the systematical compilation of books with the format was considered to foster interest in reading and public pride of Islamic books. With the reference book, Lentera Abadi wanted to provide information to the people of Indonesia about the most basic Islamic teachings that most have not been understood such as the pillars of Islam (prayer, sahadat, zakat and so on). So Lentera Abadi also had a vision to contribute to the better life of Muslims by considering the business element; further, he wanted to harmonize the two interests at the same time that the religious interest (better Islamic life) with business interests, both, must go hand in hand [9].

The second factor is 'publication as worship'. The main purpose of publishers generally was for business interests, but it turned out that there were other goals to be achieved through this publishing that was the desire to fill the void or lack of Islamic reference books in Indonesia. Therefore, although it requires a large production cost, Almahira still publishes the reference book in an attempt to fill the void. In the interview, Abdul Ghafar stressed that what he was trying to do was part of good deeds, part of worship, not merely pursuing profit. So it is very clear that Almahira makes the publishing as a pious charitable investment, while profit is the second or even third goal. If the book he published does not sell (not profitable in business) the publisher is not feeling loss even though it has spent a lot of money, because it is believed that the effort has been done is part of the worship or righteous deeds that will be obtained later in the afterlife. Almahira makes the publishing as part of the journey to the afterlife, and with that belief, according to Abdul Ghaffar, turns his books published sold well enough, this means in business this company still gains profit.

Abdul Ghafar added that the book was a medium for conveying a truth (true religious doctrine), to be read by the people and to be practiced by the people, so the publication of a book can be a charitable field whose consequence will be accepted throughout the ages (in the world and in the hereafter). Therefore, Almahira was very careful in preparing the book to be published, not in a hurry, as it must be through verification and clarification of the content so that the content was completely valid, and did not contain a mistake. For example, the Encyclopedia of Hadith required three and a half years of preparation and, of course, it costed a lot.

PT. Lentera Abadi was also very careful in publishing Islamic reference books, and had strict criteria for the publication of Islamic reference books. as a result, the books present correct information and the readers who will apply it also based on correct knowledge. Therefore, before it is published, every manuscript must be read by an expert reader consisting of a strong editorial team in language, material mastery, grammar, etc. It aims to avoid mistakes or errors in the book, so the quality, validity, and correctness of the information presented is guaranteed, and the reader will get correct information.

The third factor is improving the image for Islamic books. From the interview with Budi Sudarmono (PT Lentera Abadi), it was obtained information that so far there was assumptions that Islamic books were ugly, not good, not quality, and the price was cheap. Therefore, there should be an effort to improve the image, and that was done by PT. Lentera Abadi through the publication of Islamic references book that had much better in quality, format, contents, and packaging. Lentera Abadi publishes the Islamic reference books in order to improve the condition of the Islamic book market in Indonesia. The good and interesting Islamic books will attract the public to read them, so it is expected the reading interest will increase, this is in accordance with the ideals of this publisher to contribute in increasing the reading habit in the community. Besides, Sudharmono also added that the Indonesian people like to show off, happy to show and proud of something good or expensive, then the Islamic book must also be printed with a good format that can be exhibited and proud of the buyer. In line with Lentera Abadi, Al-Mahira also has a desire to make his books proud to his buyers and can replace the posh items in the rich people's home such as expensive jars for example. Hence Al- Mahira's books are also printed in a nice and beautiful format.

The fourth factor is that publishing is as a Syiar. From interviews with informants, it was also known that they published the book as a syiar. The publishers of the Islamic reference books (except the Ichtiar Baru van Hoeve) explicitly or implicitly declared that the Islamic book publishing they were doing was an Islamic syiar. Through publishing they wanted to contribute to a syiar in a way that was different from other conventional ways. Muhammad Kosim from PT. Kamil Pustaka stated that his publishing business was not merely pursuing the benefits of the world but also as a syiar and to get the afterlife. For that, PT. Kamil Pustaka very 
concentrated to develop an Islamic business (syariah-based business) where all business process from production to marketing run in Islamic and very emphasizing aspect of kinship. PT. Kamil Pustaka markets its products differently by the way other publishers do. For example, this publisher sets the same price on cash sales as well as on sale sales. In the familial aspect, as an example Kamil Pustaka never discharged its marketing personnel even though they failed to achieve the specified target, those who failed to achieve the target were even more embraced and given further training.

Another aspect that needs to be addressed is about the attitude of discipline, for example PT. Almahira applied high discipline for its employees especially in terms of accuracy of performing congregational prayers. In his office, PT AlMahira provides mushala and all employees are required to always pray in congregation. According to Abdul Ghafar, it was a part of to enforce the discipline of time. Perhaps it is closely related to the Al-Mahira belief that his business is a worship or a charity, then in the worship of mahdhah they must also be disciplin.

And the last factor, $\mathrm{t}$ the fifth factor, is related to the theme of the book published. Another factor contributing to the successful of Indonesian Islamic reference books publication is the 'theme' of the published books, in which each publisher has a policy on the themes of the book to be published. Lentera Abadi preferred to publish books with contemporary themes that were related to things that are happening and growing in the community, such as issues of trans gender in Islamic view, gadget issues, issues related to Islamic economics, and other issues. According to Sudharmono, PT. Lentera Abadi wanted to present Islam as a good, peaceful, wise, and cool religion, for this reason, Lentera Abadi published books that also contained good information and invite the good, things that added knowledge and insight, because those kind of books were needed by the community. Nowadays, it is not the time to publish a book in which the contents are scaring or threatening, because such a book will be shunned by the readers. Therefore the publisher (Lentera Abadi) will not accept and publish a script, even if it is good, if the theme discussed is not in accordance with the provisions.

CV. Almahira as a publisher which declared itself free of schools/sects, did not specify its themes. For Almahira, what matters was what is presented in the book is the correct information from the right source, does not contain any thoughts that endanger the domain of Islamic creed. In fact many of Almahira's books are works of translation, but in the process not only translate as they are, but are really studied and if they get thoughts that deviate or endanger the Islamic beliefs, Almahira will not publish them at all. Almahira wants to make a real contribution to the public about the true literacy culture of Islam, meaning that people should be able to obtain a true and comprehensive source of information, especially with regard to up to date issues that they feel. The works of Almahira are not only intended to enrich the treasures of Islamic culture, more importantly to provide a balance of the availability of the correct reading material required by
Muslims and acceptable by the upper middle class. Therefore, in giving an explanation of a problem, Almahira seeks to present a comprehensive discussion of different perspectives or opinions on the case including the possibility of infiltration of the author's thoughts, so that the reader will gain a balanced insight. If the author's opinion is deemed inappropriate or incorrect then it will not be published. And if there is a difference of opinion between author A, author B, author $\mathrm{C}$ and so on about a matter then first it is confirmed directly to the authors before the book is published.

\section{CONCLUSION}

The conclusion of the above discussion is that the publication of Islamic reference books in Indonesia is not only driven by economic or business factors but also influenced by non-business and ideological factors. The ideological factor consists of the beliefs and ideals of publishers they implement in policy and behavior in publishing. The publishers really believe that publishing Islamic books is a worship, not a mere business, so they must carry it seriously and carefully. Related to the ideals, all Islamic reference book publishers have a similar vision of wanting to spread knowledge and educate the public by providing reliable Islamic reference sources for all Indonesian Muslims regardless of their mazhab and flow differences.

As a suggestion for researchers who have an interest in the field of Islamic book publishing or on information sources in Islamic studies, can conduct further research on this topic. Some aspects that can be further investigated on this topic are, first, the analysis of the contents of Islamic reference books published Indonesia, the second about the relationship between the author or the contributor with the publisher of Islamic reference books, and third about how the relationship between the publishers of Islamic reference books themselves.

\section{REFERENCES}

[1] P. Wijanarko, Kebangkitan Generasi Baru: Penerbitan Buku Islam dan Masyarakat Islam Indonesia in "20 Tahun Madzhab Mizan 1983- 2003.” Bandung: Mizan, 2003.

[2] Halid and Zubair, "Peranan Penerbit dalam Transformasi Intelektualisme Islam: Survei Terhadap Beberapa Penerbit BukuBuku Islam di Daerah Khusus Ibukota Jakarta,.” Jakarta: Pusat Penelitian UIN Jakarta, 2003.

[3] Siti Maryam, "Korelasi antara Sikap Penerbit Buku Islam terhadap UU Deposit dan Pengawasan Bibliografi Buku Islam di Indonesia,." Universitas Indonesia, 2007.

[4] Sudarnoto Abdul Hakim, "'Dari Kitab Menuju Indonesia Modern,' in Transmisi Pengetahuan Timur Tengah ke Indonesia," p. 14, 2010.

[5] P. Setiawan, "'Pengertian Ideologi Menurut Para Ahli,"” 10-Apr-2015. 
[6] Abdul Ghaffar, “'Penerbitan Buku Referens Islam pada Penerbit Almahira,.” Aug-2014.

[7] Mohamad Kosim, “'Pustaka Kamil Penerbit Buku Referensi Islam,.”" Aug-2014.

[8] Starlita, “"PT. Ichtiar Baru van Hoeve,.”” Aug-2014.

[9] Budi Sudharmno, “"Penerbitan Buku Referens Islam pada PT. Lentera Abadi,.”” Aug-2014. 